\title{
Associations of diet quality with dairy group membership, membership duration and non-membership for Kenyan farm women and children: a comparative study
}

\author{
Colleen Walton ${ }^{1, *}$, Jennifer Taylor ${ }^{2}$, John VanLeeuwen ${ }^{1}$, Fiona Yeudall ${ }^{3}$ and \\ Samwel Mbugua ${ }^{4}$ \\ ${ }^{1}$ Centre for Veterinary Epidemiological Research, Atlantic Veterinary College, University of Prince Edward Island, \\ 550 University Avenue, Charlottetown, Canada, C1A 4P3: ${ }^{2}$ Department of Applied Human Sciences, University \\ of Prince Edward Island, Charlottetown, Canada: ${ }^{3}$ School of Nutrition, Centre for Studies in Food Security, \\ Ryerson University, Toronto, Canada: ${ }^{4}$ Department of Food Nutrition and Dietetics, Faculty of Health Sciences, \\ Egerton University, Egerton, Kenya
}

Submitted 1 March 2012: Final revision received 19 July 2012: Accepted 14 September 2012: First published online 30 November 2012

\begin{abstract}
Objective: To examine associations among diet quality and dairy group membership, membership duration and non-member status for women and school-aged children in rural Kenya.

Design: A cross-sectional survey, using chain referral sampling, was conducted and diet quality indices and prevalence of inadequate intake (PII) were estimated using the 'estimated average requirement' cut-off point method from single $24 \mathrm{~h}$ recalls, using a Kenyan nutrient database. PII was compared among members and non-members and among membership-duration groups.

Subjects: Women and children of dairy group members ( $n$ 88), across membership-duration groups (1-3, 4-6, 7-9 and 10+ years), and non-members ( $n$ 23) living among members.

Setting: Small farms in central Kenya.

Results: Members had higher energy, percentage of energy from animal-source foods and dietary diversity. Member women and children had lower PII for respectively seven and three of eleven micronutrients. Reduced PII for milk-source micronutrients was associated with membership duration for women. Many member women (38\%) had inadequate vitamin A intake and 39\% of member children had inadequate Zn intake. Members' PII was also high ( $>45 \%)$ for Fe, Ca and vitamin $\mathrm{B}_{12}$. A higher prevalence of being overweight among member women compared with non-member women suggested nutrition transition effects of higher farm productivity.

Conclusions: Dairy group membership was positively associated with adequate quantity and quality of diets for women and children. Long-term membership was insufficient to address micronutrient deficiencies. Understanding and addressing barriers to better diet quality and strategies to mitigate negative nutrition transition effects are needed to optimize nutritional outcomes of dairy group membership.
\end{abstract}

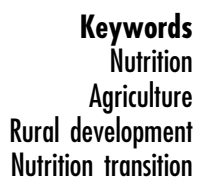

Maternal and child undernutrition is the underlying cause of 3.5 million deaths annually, with over half of mortalities among children under 5 years of age occurring in subSaharan Africa ${ }^{(1,2)}$. Widespread impacts of undernutrition include undernourished women giving birth to low-weight infants, reduced volume and quality of breast milk, and limited caring and working capacity ${ }^{(1,3)}$. The typical high-starch plant-based diets usually lack sufficient diversity and this places women, infants and school-aged children (ages 5-14 years) at risk of multiple micronutrient deficiencies $^{(4-6)}$. Inadequate intakes of $\mathrm{Fe}, \mathrm{Zn}, \mathrm{Ca}$, vitamin $\mathrm{A}$, vitamin $\mathrm{B}_{12}$ and riboflavin ${ }^{(7-9)}$ are of concern for infants and young children, and recently eleven micronutrients of concern for women in developing countries were identified $^{(10)}$. In Kenya, 35\% of children under the age of 5 years are stunted ${ }^{(11)}$, which is associated with limited cognitive development ${ }^{(12)}$. In addition, a high proportion of Kenyan children and women experience Zn (50\%, both), Fe (89 and 56\%, respectively) and vitamin A (84 and 12\%, respectively) deficiencies ${ }^{(13)}$.

The majority of the world's poor live in rural areas and many depend on small farms for food and income. 
In sub-Saharan Africa, including Kenya, smallholder farmers are challenged with limited agricultural resources ${ }^{(3)}$. Improving the productivity of small farms is considered one of the best and most sustainable means for reducing hunger and nutrition in poor rural communities ${ }^{(14-16)}$.

Wakulima Dairy Ltd (WDL), a community-based dairy group in Kenya, buys and sells members' raw milk, and provides them with regular payments and goods and services on credit. WDL member training to enhance dairy farm productivity has been conducted for more than 8 years through a partnership with Farmers Helping Farmers (FHF), a Canadian non-governmental organization, the Atlantic Veterinary College at the University of Prince Edward Island (UPEI) and the Canadian International Development Agency. Early in the training programme, FHF volunteers were concerned that farmers may opt to sell all of their milk, to the detriment of household nutrition. The training programme was then expanded to encourage households to provide children with two cups of milk each day for better school performance and health. This message, delivered by the WDL milk quality specialist, was accompanied by a two-page 'fact sheet' that reiterated the messages and included recipes to expand milk use.

Integrated participatory agriculture and nutrition interventions have demonstrated positive nutritional outcomes ${ }^{(16,17)}$; however, there is limited evidence of the effects of agricultural production interventions on individuals' nutritional outcomes $^{(16,18,19)}$. This is important for women and children, who are often disadvantaged in household food distribution. Dairy farm enhancement initiatives reported higher milk production, household income, average per-capita milk consumption and intakes of energy, total fat, protein, retinol and $\mathrm{Fe}^{(20-25)}$. Our previous results found WDL membership duration longer than 3 years was positively associated with higher milk production and that members had higher average per-capita milk availability compared with non-members $(0.6 v .0 .3 \mathrm{l} / \text { person per } \mathrm{d})^{(26)}$. Longer duration and intensity of involvement in an integrated agricultural and nutrition project had positive impacts on height and weight of children (under 3 years of age) in Malawi ${ }^{(17)}$ but no other reports detailing the duration impact of agricultural intervention, including enhanced dairy farming, on health and nutrition were identified.

The objectives of the present study were to examine associations among dairy group membership, membership duration and non-member status with diet quality indicators and prevalence of inadequate nutrient intakes for women and school-aged children in rural Kenya.

\section{Methods}

\section{Setting}

WDL is located in Mukurweini Division, Central Province, Kenya. Farmer members live along four rural routes and around a central town. Non-member farmers live among the dairy group members throughout the division. The 6000 dairy group member households represent about $28 \%$ of the division's population of 83932 (2009).

\section{Study design and sampling metbod}

A cross-sectional survey of eighty-eight WDL member households, evenly distributed over four membership duration 'study groups' (1-3, 4-6, 7-9 and 10+ years), and twenty-three non-member households was conducted in August 2009. The sample size was established to generate data with reasonable power, balanced with limited resources, and included $10 \%$ additional participants to maintain numbers in case of spoiled surveys.

Study group members in the four duration groups were identified using chain referral sampling since there was no available list of members with duration status or contact information to use in selecting a stratified random sample $\mathrm{e}^{(27,28)}$. Eight WDL members were selected to initiate the referrals. These initiators represented a wide range of age, geographic distribution and involvement within the dairy group. Each initiator referred farmer members that represented the four membership-duration groups. The research team contacted referred members to confirm membership duration. This procedure was repeated until sufficient numbers of members in each membershipduration group were identified. Referred WDL members were asked to identify non-members to generate a nonmember list ( $n$ 50). The non-member participants ( $n$ 23) were randomly selected from this list. Directors and managers of WDL and teachers were excluded from the study in order to focus the research on households with farming as their primary livelihood strategy.

\section{Survey and dietary assessments}

The interview was conducted in person by two trained interviewers, including the first author, using translators as needed. Demographic information was collected from the household adult(s) and women were interviewed for food preparation and consumption using a four-pass $24 \mathrm{~h}$ recall $^{(29)}$. Dietary intake was recorded for the women and for a randomly selected child in households with at least one daily resident child (biological, grandchild or adopted) aged between 5 and 14 years. Children do not attend school in August, which was the time of the survey; when available, children verified food intake reported by the mother and provided information on additional foods consumed. In two households, the father was the main food preparer and was similarly interviewed, but only data for the child's food intake were analysed. Interviews were conducted to ensure each day of the week was evenly represented in the recalls for each membership group.

Women's weight was measured using a 'Salter-Speedo' dial mechanical scale (model $148 ; 0.5 \mathrm{~kg}$ accuracy). Height was measured using a rigid measuring tape $(0 \cdot 1 \mathrm{~cm}$ accuracy) and a square angle. Whenever possible, women stood on level ground next to a vertical surface. 
Height and weight measurements were used to compute BMI for each woman. Children's weights and heights were not measured, as not all children were always available during data collection.

Ingredients in mixed dishes obtained from the $24 \mathrm{~h}$ recall were quantified by: (i) weighing directly; (ii) using home measures (e.g. scoop, heaped tin) with standard food densities; or (iii) estimated from locally purchased items (e.g. tomato, cabbage). The volume of cooked mixed dishes was computed using the pot circumference or diameter and food height. When no recipe was provided (e.g. ate at neighbours) or the recipe and yield were contradictory, an average recipe, based on ten randomly selected household recipes within the survey, was used to estimate nutrient intakes.

Portions served were estimated by the women placing dried beans into the individual's bowl to represent the serving. When leftover food was reported, the leftover volume was estimated using the dried beans and removed, leaving the portion consumed. The beans representing the portion consumed were weighed and the bean density used to estimate the volume of food consumed. The same dried beans were used throughout. The quantity of mixed dish ingredients consumed was computed as a fraction of the recipe yield. Liquid food intakes, mainly tea and thin porridge (uji), were estimated from the mass of water in the individual's cup or from the commercial volume for purchased beverages. Food and beverage intakes were used to compute diet quality indices and to estimate nutrient intakes.

\section{Data analysis}

Milk intake and dietary diversity were estimated from results of the $24 \mathrm{~h}$ recall. Dietary diversity was computed using a nine food-group indicator, with a $15 \mathrm{~g}$ minimum intake, validated for use in resource-poor settings ${ }^{(10)}$. The mean dietary diversity (number of different food groups consumed) was computed for each membership group.

Energy, distribution of dietary energy and nutrient intakes were computed using the World Food Dietary Assessment System Version 2·0 (Wfood2) and the Kenyan food composition database ${ }^{(30)}$. Foods not found in this database were imported from other databases within Wfood2 or imputed from US Department of Agriculture or Canadian Nutrient File values. Median (first quartile (Q1), third quartile (Q3)) nutrient intakes were computed. Wfood2 estimates bioavailable $\mathrm{Fe}$ and $\mathrm{Zn}$ intake using adjustments for enhancing and interfering factors in the same meal. Both $\mathrm{Fe}$ and $\mathrm{Zn}$ status was assumed to be basal for these availability adjustments.

Women's energy intakes were examined for over- and under-reporters, using a high physical activity level $(3 \cdot 0)$ and the Goldberg method ${ }^{(10,31)}$. Data for women with energy intake outside the range $5230-17400 \mathrm{~kJ}(1250-4160 \mathrm{kcal})$ were examined for errors and plausibility and excluded from analysis as applicable. Data from nursing women were also excluded.
Women's milk consumption, energy, percentage energy sources and dietary diversity were analysed to examine associations with membership status and membership duration, using the $t$ test or ANOVA with Bonferroni multiple comparison adjustment. Associations of diet quality indicators with membership duration were examined using linear regression. Children's milk consumption, energy and percentage energy distribution were compared between members and non-members using the $t$ test for normally distributed variables and the Mann-Whitney test for variables not following a normal distribution. Normal distribution was assessed using the Shapiro-Wilk test and transformations were applied to some variables to achieve a normal distribution.

Estimates of the prevalence of inadequate intakes (PII) were computed using the Estimated Average Requirement cut-point $\operatorname{method}^{(32)}$, with the following exceptions: (i) women's energy intake was compared with $9414 \mathrm{~kJ}$ $(2250 \mathrm{kcal})$, the average daily energy requirement for Kenya $^{(33)}$; (ii) Ca was assessed using Adequate Intake values; (iii) protein and available $\mathrm{Zn}$ and Fe requirements were estimated using women's ages, weights (or median study group weight, $61.4 \mathrm{~kg}$, for twenty women without measured weight) and mean requirements (and for women under 50 years of age, $0.48 \mathrm{mg} \mathrm{Fe} / \mathrm{d}$ requirement was added for menstrual losses); and (iv) children's energy, protein and available $\mathrm{Fe}$ and $\mathrm{Zn}$ requirements were compared with the children's mean requirements ${ }^{(32)}$ based on mean age and 25 th percentile weight-for-age ${ }^{(34,35)}$.

Significant associations of PII among membership groups (women only) and between members and nonmembers were examined using $\chi^{2}$ analysis.

Recipe calculations were performed using Microsoft ${ }^{\circledR}$ Excel v 6. Statistical analysis was conducted using the Stata 10 statistical software package. Significance was assessed at $P<0.05$ for women and, with the small sample size, at $P<0 \cdot 10$ for children.

Approval to conduct the study was obtained through FHF, WDL and the UPEI Research Ethics Board prior to conducting the study. Written consent was obtained from all participants after the nature of the study had been fully explained to them.

\section{Results}

All dairy group members approached agreed to participate in the survey (100\% response). Women in two non-member households refused to participate, and the next household on the list was approached. Energy intakes were examined for over- and under-reporters. As a result, data from two women were excluded from the analysis. Intakes from other women with high or low energy were retained as data seemed probable, given other information. One woman being treated for anaemia was excluded. 
Table 1 Median (Q1, Q3) milk consumption ( $\mathrm{g} / \mathrm{d}$ ) by dairy group membership, cattle ownership and cow lactation status among women and school-aged children, Mukurweini Division, Central Province, Kenya, August 2009

\begin{tabular}{|c|c|c|c|c|c|c|}
\hline & \multicolumn{3}{|c|}{ Non-members } & \multicolumn{3}{|c|}{ All members } \\
\hline & Median & Q1, Q3 & $n$ & Median & Q1, Q3 & $n$ \\
\hline Women (all) & $162^{\mathrm{a}}$ & 55,267 & 20 & $440^{\mathrm{b}}$ & 288,758 & 82 \\
\hline Children & $37^{\mathrm{a}}$ & 0,90 & 16 & $201^{\mathrm{b}}$ & 98,360 & 46 \\
\hline Women (no cattle) & 108 & 27,268 & 8 & 570 & - & 1 \\
\hline Women (cattle, none lactating) & $165^{\mathrm{a}}$ & 88,243 & 8 & $267^{\mathrm{b}}$ & 206,411 & 18 \\
\hline Women (lactating cow) & $256^{\mathrm{a}}$ & 92,374 & 4 & $500^{\mathrm{b}, *}$ & 360,892 & 63 \\
\hline
\end{tabular}

Q1, first quartile; Q3, third quartile.

${ }_{\mathrm{a}, \mathrm{b}}$ Median values within a row with unlike superscript letters were significantly different $(P<0.05)$.

*Member women with a lactating cow consumed more milk than member women without a lactating cow $(t$ test): $P<0 \cdot 05$.

Women's age increased with membership duration, as expected, and ranged from 35 years in the groups with membership duration of $1-3$ and $4-6$ years, to 43 and 53 years respectively in the membership-duration groups of 7-9 and $10+$ years. The average age of women members ( 41.5 years) and non-members ( 43.9 years) was not different. Age and the proportions of girls and boys were not different between member and non-member children (age 8.6 and 8.4 years, respectively).

\section{Diet quality indicators}

Milk intake was higher for member children and women compared with non-members (Table 1). Member women with lactating cow(s) had significantly higher milk intake than those without lactating $\operatorname{cow}(\mathrm{s})$. A similar trend was observed for non-member women with and without lactating $\operatorname{cow}(\mathrm{s})$. Women's milk intake was also positively associated with membership duration (data not shown; $\left.R^{2}=0 \cdot 24\right)$.

Member women had higher energy intakes and weight status (BMI) than non-members (Table 2). Women's overweight status (BMI $\geq 25 \mathrm{~kg} / \mathrm{m}^{2}$ ) was associated with dairy group membership, with $54 \%$ of members and $29 \%$ of non-members classified as overweight. In addition, members had a higher percentage of energy from animalsource foods (ASF) and from saturated fat compared with non-members. Membership duration was negatively associated with the percentage of energy from carbohydrates $\left(R^{2}=0 \cdot 11\right)$ and positively associated with the percentage of energy from ASF $\left(R^{2}=0 \cdot 17\right)$ and percentage of energy from saturated fat $\left(R^{2}=0 \cdot 13\right)$.

Similarly, member children consumed more energy than non-member children, and had a lower percentage of energy from carbohydrates, a higher percentage of energy from ASF and a higher percentage of energy from fat than non-members (Table 3). Energy from flesh foods (meat, fish and poultry) was negligible for all women and children.

Dietary diversity was greater for member women than non-members but not different among membershipduration groups (Table 4). Few women, in any group, consumed organ meat, eggs or flesh foods.

\section{Nutrient intake and prevalence of inadequate intake}

Member women had higher median intakes of macronutrients and most micronutrients (except thiamin, niacin, folate and vitamin C) than non-members (data not shown). Women's micronutrient intakes per kilojoule were positively associated with membership duration for riboflavin, vitamin $\mathrm{B}_{12}$, vitamin $\mathrm{A}$ from $\mathrm{ASF}, \mathrm{Ca}$ and available $\mathrm{Zn}$. Phytate densities of women's diets were not different between members and non-members.

Member women had lower PII for energy, protein and micronutrients (except thiamin, niacin, $\mathrm{Zn}$ and $\mathrm{Fe}$ ) compared with non-member women (Table 5). Longer WDL membership duration was associated with lower PII for riboflavin, vitamin $\mathrm{B}_{12}$ and $\mathrm{Ca}$ and higher PII for niacin (data not shown).

Children from member households had significantly higher intakes of protein, fat, vitamin A from ASF, Ca, riboflavin, vitamin $\mathrm{B}_{6}$ and vitamin $\mathrm{B}_{12}$ compared with non-member children (data not shown). The PII for member children was significantly lower for riboflavin, folate and vitamin $\mathrm{B}_{12}$, and marginally lower for energy $(P=0 \cdot 11$; Table 5$)$. The PII for vitamin $\mathrm{B}_{12}, \mathrm{Ca}, \mathrm{Zn}$ and $\mathrm{Fe}$ was $>40 \%$ for all children.

Women's median Na intake was $1155 \mathrm{mg}$ (Q1, Q3 670, $1725 \mathrm{mg}$ ). Na intake was not different among groups but was positively associated with membership duration. One-quarter of member women exceeded the recommended population average $\mathrm{Na}$ intake $(2000 \mathrm{mg} / \mathrm{d})^{(36)}$.

\section{Discussion}

\section{Diet quality indicators}

Previous studies have reported higher household milk consumption with higher dairy farm productivity ${ }^{(20,23,37,38)}$. Our study revealed that WDL member women and children consumed significantly more milk. Median milk intake for member children $(201 \mathrm{~g} / \mathrm{d})$ indicated that $50 \%$ of member children had the potential for the health, growth and cognitive benefits associated with the daily consumption of $200 \mathrm{ml}$ of milk ${ }^{(8,39-41)}$. Member women's milk consumption 
was significantly higher with a lactating cow than without a lactating cow. A similar trend was observed for nonmembers, although the low numbers limited the statistical power. Farm management to reduce the 'dry period' for cows, and/or ownership of more than one cow with varied lactations, is therefore likely to have nutritional benefits for women and children.

Milk in Kenya is consumed primarily in tea, and the proportion of milk in the tea can vary widely. Tannins in tea reduce $\mathrm{Fe}$ bioavailability ${ }^{(42)}$, and if member women and children are drinking more tea, there may be a negative impact on Fe status; this merits further investigation. Consumption of less milk than promoted ('two cups daily') by member children may be due, in part, to limits in the amount of tea a child can consume, and reinforces the need to promote milk consumption. Milk intake from the $24 \mathrm{~h}$ recall was lower than our reported average percapita household milk availability $(0.6 \mathrm{l} / \text { person per } \mathrm{d})^{(26)}$, which suggests that average per-capita household milk availability may overestimate individual milk consumption when assessing the impact of dairy intensification. This difference may be explained by uneven intra-household allocation, sharing milk or tea with visitors and neighbours, or using milk for calf rearing.

Our survey was conducted in August 2009 prior to harvest and following a drought and crop failure, when food shortages occurred ${ }^{(43)}$. Member women had a lower PII for energy that corresponded with their higher median weight status, which may relate to staple foods (e.g. maize, flour) being available on credit to members. Despite higher median energy intake for member children, the PII for energy was high for members and non-members. Some instances of under-reported energy may have occurred. In one study, when children were not available to modify food intakes reported by their mothers, energy intakes were under-reported by 13-19\% ${ }^{(44)}$. However, comparisons between groups would still likely be valid, with non-differential underreporting, although the PII figures for children may be slightly inflated. Children's protein intake was mostly adequate, as expected with the traditional diet ${ }^{(45)}$.

Members' energy distribution was in line with WHO recommendations, in contrast to that of non-members ${ }^{(36)}$. Members had a higher percentage of energy from ASF and dietary diversity, that indicated higher diet quality compared with non-members ${ }^{(10)}$. Women members' median percentage of energy from ASF reflected Kenyan food availability $(11 \%)^{(13)}$. A wide range of percentage of energy from ASF has been reported: from $40 \%$ for Egyptian women ${ }^{(46)}$, to $26-32 \%$ for dairy farm women in Rift Valley, Kenya ${ }^{(25)}, 3-12 \%$ for women in resource-poor settings $^{(4)}$ and $0-4 \%$ for poor Ethiopian women ${ }^{(47)}$. Three-quarters of member children exceeded $4 \%$ of energy from ASF observed for Kenyan schoolchildren ${ }^{(39)}$, but few reached the $11 \%$ available ASF in Kenya ${ }^{(13)}$ or the 9.8-12\% reported for urban Ugandan children ${ }^{(48)}$. 
Table 3 Median (Q1, Q3) dietary energy and energy distribution by dairy group membership among school-aged children, Mukurweini Division, Central Province, Kenya, August 2009

\begin{tabular}{|c|c|c|c|c|c|}
\hline & \multicolumn{2}{|c|}{ Non-members (n 16) } & \multicolumn{2}{|c|}{ Members ( $n$ 46) } & \multirow[b]{2}{*}{ Reference values } \\
\hline & Median & Q1, Q3 & Median & Q1, Q3 & \\
\hline Energy $(\mathrm{kJ} / \mathrm{d})$ & $5022^{\mathrm{a}}$ & 3625,8420 & $7225^{\mathrm{b}}$ & 5744,10113 & \\
\hline$\% \mathrm{E}$ from protein & 11 & 10,12 & 11 & 10,13 & $10-15 \%+$ \\
\hline$\% \mathrm{E}$ from $\mathrm{CHO}$ & $80^{\mathrm{a}}$ & 77,85 & $74^{\mathrm{b}}$ & 68,77 & $55-75 \%+$ \\
\hline$\%$ from fat & $13^{\mathrm{a}}$ & 11,19 & $19^{\mathrm{b}}$ & 14,27 & $15-35 \%+$ \\
\hline$\%$ from ASF & $2 \cdot 2^{a}$ & $1 \cdot 0,5 \cdot 8$ & $6 \cdot 6^{\mathrm{b}}$ & $4 \cdot 1,11 \cdot 0$ & $11 \% \ddagger$ \\
\hline
\end{tabular}

Q1, first quartile; Q3, third quartile; \%E, percentage of energy; $\mathrm{CHO}$, carbohydrate; $\mathrm{ASF}$, animal-source foods.

${ }_{\mathrm{a}, \mathrm{b}}$ Median values within a row with unlike superscript letters were significantly different $(P<0.05)$.

+WHO guidelines ${ }^{(36)}$.

¥Kenya food supplies' \%E from ASF $^{(13)}$.

Table 4 Percentage of women consuming each food group and mean (standard error) dietary diversity score by dairy group membership, Mukurweini Division, Central Province, Kenya, August 2009

\begin{tabular}{lcc}
\hline & Non-members $(n$ 20) & All members $(n$ 82) \\
\hline Starch & 100 & 100 \\
Legumes/nuts & 82 & 76 \\
Dairy (milk) & 95 & 100 \\
Organ meats & 0 & 2 \\
Eggs & 5 & 6 \\
Flesh foods & 9 & 8 \\
Leafy greens (vitamin A) & $32^{\mathrm{a}}$ & $55^{\mathrm{b}}$ \\
Other vitamin A fruit/vegetables & 27 & 31 \\
Other fruit/vegetables & $64^{\mathrm{a}}$ & $87^{\mathrm{b}}$ \\
Dietary diversity score & & $4 \cdot 7^{\mathrm{b}}$ \\
Mean & $4 \cdot 1^{\mathrm{a}}$ & $0 \cdot 10$ \\
\hline SE & $0 \cdot 19$ & \\
\hline
\end{tabular}

${ }^{a, b}$ Values within a row with unlike superscript letters were significantly different $(P<0.05)$.

Table 5 Prevalence (\%) of inadequate intake by dairy group membership among women and school-aged children, Mukurweini Division, Central Province, Kenya, August 2009

\begin{tabular}{|c|c|c|c|c|}
\hline & \multicolumn{2}{|c|}{ Women } & \multicolumn{2}{|c|}{ Children } \\
\hline & $\begin{array}{c}\text { Non-members } \\
(n 20)\end{array}$ & $\begin{array}{l}\text { All members } \\
(n \text { 82) }\end{array}$ & $\begin{array}{c}\text { Non-members } \\
(n 16)\end{array}$ & $\begin{array}{c}\text { Members } \\
(n \text { 46) }\end{array}$ \\
\hline Energy & $80^{a}$ & $44^{b}$ & 69 & 44 \\
\hline Protein & $43^{a}$ & $18^{\mathrm{b}}$ & 6 & 4 \\
\hline Thiamin & 20 & 11 & 0 & 0 \\
\hline Riboflavin & $70^{a}$ & $13^{\mathrm{b}}$ & $36^{\mathrm{a}}$ & $13^{\mathrm{b}}$ \\
\hline Niacin & 45 & 43 & 25 & 13 \\
\hline Vitamin $B_{6}$ & $50^{a}$ & $13^{\mathrm{b}}$ & 0 & 0 \\
\hline Folate & $40^{\mathrm{a}}$ & $18^{\mathrm{b}}$ & $19^{a}$ & $4^{b}$ \\
\hline Vitamin $\mathrm{B}_{12}$ & $100^{\mathrm{a}}$ & $61^{\mathrm{b}}$ & $88^{a}$ & $63^{b}$ \\
\hline Vitamin A & $65^{a}$ & $38^{\mathrm{b}}$ & 38 & 22 \\
\hline Vitamin C & $50^{\mathrm{a}}$ & $23^{b}$ & 6 & 2 \\
\hline $\mathrm{Ca}$ & $100^{\mathrm{a}}$ & $61^{\mathrm{b}}$ & 100 & 87 \\
\hline $\mathrm{Zn}$ & 20 & 14 & 50 & 39 \\
\hline $\mathrm{Fe}$ & 70 & 65 & 63 & 59 \\
\hline
\end{tabular}

${ }^{\mathrm{a}, \mathrm{b}}$ Values within a row with unlike superscript letters were significantly different $(P<0.05)$, women and children analysed separately.

The positive association of women's percentage of energy from ASF with membership duration suggests nutritional benefits of sustained WDL membership. The higher percentage of energy from ASF, even for long-term members, was explained by milk, not flesh food, consumption. ASF consumption is often limited by resources. Our $24 \mathrm{~h}$ recall method may not have been sufficiently sensitive to detect an increase in consumption of flesh foods, if there was one. Using an FFQ, $86 \%$ of Tanzanian dairying households reported consuming meat/fish more than five times per month compared with $56 \%$ of non-dairying households ${ }^{(24)}$. Future studies could benefit from inclusion of food frequency data which may reflect broader changes to the dietary pattern associated with dairy group membership duration. Modestly higher dietary diversity may reflect access to rented land ${ }^{(26)}$ that enabled 
members to grow a greater variety of food crops and/or that dairy income enabled the purchase of additional (non-ASF) foods.

\section{Micronutrients}

Members had significantly higher micronutrient intakes and lower PII values that reflected higher energy intake, percentage of energy from ASF and dietary diversity. Milk nutrients figured prominently in associations of women's nutrient intakes and PII with membership duration. Benefits to members' health and productivity, and specifically children's vitamin $\mathrm{B}_{12}$ status, are expected ${ }^{(8,49)}$. Lower PII for vitamin $C$ and folate can be attributed to higher dietary diversity (leafy greens, other fruits and vegetables). Despite positive change, PII for micronutrients remained high for women and children and reflected relatively low dietary diversity and intake of flesh foods ${ }^{(4,5,40)}$. Inadequate intakes have negative inter-generational impacts that include poor pregnancy outcomes, reduced or delayed infant growth and development, and reduced personal health and productive capacity.

Children's high PII for Zn, in contrast with women's, may be related to children's lower energy and milk intakes and their high $\mathrm{Zn}$ requirement. High seasonal consumption of mangoes, by children but not women, may explain children's lower PII for vitamins A and $C^{(10,44)}$. Seasonal differences in food patterns and dietary diversity of Ghanian, Malawian and rural Benin children have also been reported ${ }^{(50,51)}$.

\section{Nutrition transition}

Women's weight status and intakes of saturated fat and $\mathrm{Na}$ were examined, as even small income increases have been associated with a transition from under- to overnutrition. This transition is characterized by the consumption of a 'Western diet' (high in saturated fat, sugar and refined foods, and low in fibre) and is associated with a higher prevalence of chronic disease ${ }^{(52)}$. The higher proportion of overweight member women reflects this transition and is an area of concern. Energy from saturated fat remained below the recommended level (10\%) and median intake was lower than that reported previously for rural Kenyan women (17·2 $\mathrm{g} / \mathrm{d})^{(53)}$. However, energy from saturated fat and Na were positively associated with membership duration.

\section{Study limitations}

Limitations in the present research need to be considered in the interpretation of the results. First, the cross-sectional design limits conclusions concerning causality between dairy group membership (or duration) and specific outcomes. Stratified random sampling, although preferable, was not possible, necessitating the use of chain referral sampling. To reduce potential bias from chain referral sampling, the survey list was generated using multiple chains, initiated through individuals with a wide range of age, geographic location and involvement within the dairy group. Further research, using a longitudinal study design and a randomized sample, would help fulfill the criteria for causality needed to conclude the hypothesized 'impacts' of WDL membership.

Second, the use of a single $24 \mathrm{~h}$ recall, and inability to adjust for usual intake, leads to greater variability in the nutrient intake distributions. The resulting intake estimates are valid for comparing medians across groups $^{(54,55)}$. Using unadjusted intakes to estimate PII may over- or underestimate these values. In addition, pregnant women were not identified systematically and their higher nutritional requirements were not factored into analyses. This could lead to an underestimation of women's PII values, although this would be a nondifferential bias among both members and non-members. As a result, our PII figures are valid for comparison between groups in the study, but may have limited comparability to other situations. A four-pass $24 \mathrm{~h}$ recall, with trained interviewers, was used to maximize the food recall and local measures were used to maximize the accuracy of measurements ${ }^{(56)}$; however, random error may still be involved in these estimates. For example, women may deliberately over- or under-report intakes if motivated by pride or seeking aid. This potential error was addressed, in part, by clearly explaining the nature and purpose of the study in advance and through appropriate exclusion of observations with unlikely high and low energy intakes. All reasonable efforts were made to accurately measure heights and weights, although it was sometimes a challenge to find a suitable level surface. The non-differential error resulting from small inaccuracies in height measurement should not detract from the importance of the BMI findings.

Third, we were unable to assess membership duration for children's intakes due to lower than expected numbers of children. Consequently, member and non-member schoolchildren were compared. Children's intakes may be under-reported when children were not available to contribute to the intake estimation ${ }^{(44)}$. This may limit comparability of our results, but comparisons between groups within the study remain valid.

Finally, the comparison of our $\mathrm{Zn}, \mathrm{Fe}$ and vitamin A results may be limited. Intakes reported here were corrected for absorption-enhancing (e.g. vitamin C) and -inhibiting factors (e.g. phytate, tannins). As well, the bioconversion factors for $\beta$-carotene (1:12) and other carotenoids (1:24) to vitamin A (retinol equivalents) were half that previously used, based on more recent evidence ${ }^{(30)}$.

\section{Conclusions}

Our study presents positive dietary associations with semi-commercial dairy farming, within a dairy group, that can potentially improve member women's and schoolchildren's health and capacities. Our results contrast those of cash-cropping schemes in six developing countries 
in Africa, Asia and Latin America that had no short-term positive or adverse nutritional effects ${ }^{(57)}$ and others that suggested the higher prevalence of malnutrition among children in Western Kenya was due to parents being involved in cash-crop farming rather than mixed farming ${ }^{(58)}$. Duration of membership was associated with lower prevalence of inadequate intake for some micronutrients, particularly those in milk. Micronutrient deficiencies were not, however, fully addressed by WDL membership and women and children remain at risk of undernutrition, even with long-term dairy group membership. In addition, member women's weight status and trends in saturated fat and $\mathrm{Na}$ consumption represent areas of concern.

These results highlight the need to modify the typical diet of rural Kenyan women and children, and support assertions that increased income from dairy was used for purchases other than nutritious food ${ }^{(20,38)}$. To enhance positive and mitigate negative nutritional effects of dairy projects, activities should be expanded to include nutrition education, numeracy, literacy and complementary agricultural activities. These additions were associated with positive nutrition impacts in a dairy goat production project ${ }^{(47)}$. A review of agricultural interventions revealed that investing in more than three of the recognized livelihood assets, in particular nutrition education of women, had the greatest nutritional impact ${ }^{(16,59)}$, which is in keeping with the recommendation for more productive collaborations between agricultural and nutritional sciences ${ }^{(60)}$.

Specific strategies for dietary modification, within this resource-limited setting, include strengthening efforts to increase children's milk consumption, initiating complementary interventions to enable the consumption of nutrient-dense foods (e.g. flesh and organ meats, fruit and vegetables) and promoting the use of food-based strategies that improve $\mathrm{Zn}$ and Fe bioavailability in plant foods ${ }^{(54)}$. In addition, there is a need to monitor the nutritional transition within development initiatives.

\section{Acknowledgements}

Sources of funding: This research was supported by the Veterinarians without Borders and the XXIII World Veterinary Congress Foundation. Conflicts of interest: None of the authors have any conflicts of interest. Authors' contributions: C.W. wrote the manuscript with input from the other authors. J.V. and C.W. developed the study hypothesis and proposal and secured the funding. C.W. and S.M. were the field leaders and coordinators, and participated in data collection. C.W. performed data analysis, and J.T. and F.Y. assisted in interpretation of the data. Acknowledgements: The cooperation of FHF and WDL, and the openness and honesty of member and non-member farmers, are truly appreciated. The efforts of Regina Gitau, Lisa Wolff and Ruth Wanjiro were paramount for locating the many rural households, providing translation, and patiently and persistently conducting the survey.

\section{References}

1. Black RE, Allen LH, Bhutta ZA et al. (2008) Maternal and child undernutrition: global and regional exposures and health consequences. Lancet 371, 243-260.

2. Murray CJ, Laakso T, Shibuya K et al. (2007) Can we achieve Millennium Development Goal 4? New analysis of country trends and forecasts of under-5 mortality to 2015 . Lancet 370, 1040-1054.

3. Food and Agriculture Organization of the United Nations (2006) The State of Food Insecurity in the World 2006. http://www.fao.org/docrep/009/a0750e/a0750e00.htm (accessed November 2011).

4. Arimond M, Wiesmann D, Becquey E et al. (2010) Simple food group diversity indicators predict micronutrient adequacy of women's diets in 5 diverse, resource-poor settings. J Nutr 140, issue 11, 2059S-2069S.

5. Arimond M \& Ruel MT (2004) Dietary diversity is associated with child nutritional status: evidence from 11 demographic and health surveys. J Nutr 134, 2579-2585.

6. Best C, Neufingerl N, van Geel L et al. (2010) The nutritional status of school-aged children: why should we care? Food Nutr Bull 31, 400-417.

7. UNICEF (2008) UNICEF Humanitarian Action Report 2008. Humanitarian Action in Kenya. http://www.unicef. org/har08/files/har08_Kenya_countrychapter.pdf (accessed November 2011).

8. Siekmann JH, Allen LH, Bwibo NO et al. (2003) Kenyan school children have multiple micronutrient deficiencies, but increased plasma vitamin B-12 is the only detectable micronutrient response to meat or milk supplementation. J Nutr 133, 11 Suppl. 2, 3972S-3980S.

9. Neumann CG, Bwibo NO, Murphy SP et al. (2003) Animal source foods improve dietary quality, micronutrient status, growth and cognitive function in Kenyan school children: background, study design, and baseline findings. $J$ Nutr 133, 11 Suppl. 2, 3941S-3949S.

10. Wiesmann D, Arimond M \& Loechl C (2009) Dietary Diversity as a Measure of the Micronutrient Adequacy of Women's Diets: Results from Rural Mozambique Site. http://www.fantaproject.org/downloads/pdfs/WDDP_Moza mbique_Dec09.pdf (accessed November 2011).

11. Kenya National Bureau of Statistics \& ICF Macro (2010) Kenya Demographic and Health Survey 2008-09. http:// www.measuredhs.com/pubs/pdf/FR229/FR229.pdf (accessed November 2011).

12. Grantham-McGregor S, Cheung YB, Cueto S et al. (2007) Child development in developing countries 1: developmental potential in the first 5 years for children in developing countries. Lancet 369, 60-70.

13. Food and Agriculture Organization of the United Nations (2005) Kenya Nutrition Profile. ftp://ftp.fao.org/es/esn/ nutrition/ncp/ken.pdf (accessed November 2011).

14. Food and Agriculture Organization of the United Nations (2003) Anti-Hunger Programme. A twin-track approach to hunger reduction: priorities for national and international action. http://www.fao.org/docrep/006/j0563e/j0563e00.htm (accessed November 2011).

15. Matshe I (2009) Boosting smallholder production for food security: some approaches and evidence from studies in sub-Saharan Africa. Agrekon 48, 483-510.

16. Berti PR, Krasevec J \& FitzGerald S (2004) A review of the effectiveness of agriculture interventions in improving nutrition outcomes. Public Health Nutr 7, 599-609.

17. Bezner Kerr R, Berti PR \& Shumba L (2011) Effects of a participatory agriculture and nutrition education project on child growth in northern Malawi. Public Health Nutr 14 , 1466-1472. 
18. Leroy JL \& Frongillo EA (2007) Can interventions to promote animal production ameliorate undernutrition? J Nutr 137, 2311-2316.

19. Bhutta ZA, Ahmed T, Black RE et al. (2008) What works? Interventions for maternal and child undernutrition and survival. Lancet 371, 417-440.

20. Mullins G, Wahome L, Tsangari P et al. (1996) Impacts of intensive dairy production on smallholder farm women in coastal Kenya. Hum Ecol 24, 231-253.

21. Tangka F, Ouma EA \& Staal JS (1999) Women and the sustainable development of market-oriented dairying: evidence from the highlands of East Africa. http://mahider. ilri.org/handle/10568/1931 (accessed November 2011).

22. Ahmed MM, Jabbar M \& Ehui S (2000) Household-level economic and nutritional impacts of market-oriented dairy production in the Ethiopian highlands. Food Nutr Bull 21, 460-465.

23. Kisusu RW, Mdoe NSY, Turuka FM et al. (2000) Contribution of smallholder dairy production to food security, household income and poverty alleviation: the case of Mvumi dairy development project, Dodoma. Tanzanian Vet J 20, 89-99.

24. Lwelamira J, Binamungu HK \& Njau FB (2010) Contribution of small scale dairy farming under zero-grazing in improving household welfare in Kayanga ward, Karagwe District, Tanzania. Livestock Res Rural Dev 22, article \#31; available at http://www.lrrd.org/lrrd22/2/lwel22031.htm

25. Huss-Ashmore R (1996) Livestock, nutrition, and intrahousehold resource control in Uasin Gishu district, Kenya. Hum Ecol 24, 191-213.

26. Walton C, VanLeeuwen J, Yeudall F et al. (2012) Associations between duration of community-based group membership and sustainable livelihoods for Kenyan women dairy farmers. I Agric Food Syst Community Dev 3, issue 1; available at http://dx.doi.org/10.5304/jafscd.2012.031.002

27. Biernacki P \& Waldorf D (1981) Snowball sampling: problems and techniques of chain referral sampling. Sociol Methods Res 10, 141-163.

28. Penrod J, Preston DB, Cain RE et al. (2003) A discussion of chain referral as a method of sampling hard-to-reach populations. J Transcult Nurs 14, 100-107.

29. Gibson RS (1990) Principles of Nutritional Assessment. New York: Oxford University Press.

30. Bunch S, Murphy S (1997) World Food Dietary Assessment System Version 2. http://www.fao.org/fileadmin/templates/ food_composition/documents/WORLDFOOD_DIETARY_ ASSESSMENT_SYSTEM_2_.pdf (accessed June 2009).

31. Black AE (2000) Critical evaluation of energy intake using the Goldberg cut-off for energy intake:basal metabolic rate. A practical guide to its calculation, use and limitations. Int J Obes Relat Metab Disord 24, 1119-1130.

32. Food and Nutrition Board, Institute of Medicine, National Academies (2010) Dietary Reference Intakes (DRIs): Estimated Average Requirements. http://iom.edu/Activities/ Nutrition/SummaryDRIs/ /media/Files/Activity\%20Files/ Nutrition/DRIs/EAR\%20Table.pdf (accessed November 2011).

33. Food and Agriculture Organization of the United Nations (2010) Country Profile: Food Security Indicators: Kenya. http://www.fao.org/fileadmin/templates/ess/documents/food security_statistics/country_profiles/eng/Kenya_E.pdf (accessed January 2012).

34. World Health Organization (2007) Growth reference data for 5-19 years. http://www.who.int/growthref/en/ (accessed November 2011).

35. Murphy SP, Beaton GH \& Calloway DH (1992) Estimated mineral intakes of toddlers: predicted prevalence of inadequacy in village populations in Egypt, Kenya, and Mexico. Am J Clin Nutr 56, 565-572.

36. World Health Organization (2003) Diet, Nutrition and the Prevention of Chronic Diseases. Report of a Joint WHO/ FAO Expert Consultation. WHO Technical Report Series, no. 916. Geneva: WHO; available at http://whqlibdoc. who.int/trs/who_trs_916.pdf (accessed November 2011).

37. Nicholson CF, Mwangi L, Staal SJ et al. (2003) Dairy cow ownership and child nutritional status in Kenya. http://ageconsearch.umn.edu/bitstream/22154/1/sp03ni01.pdf (accessed November 2011).

38. Nicholson CF, Thornton PK \& Muinga RW (2004) Household-level impacts of dairy cow ownership in coastal Kenya. J Agric Econ 55, 175-195.

39. Grillenberger M, Neumann CG, Murphy SP et al. (2006) Intake of micronutrients high in animal-source foods is associated with better growth in rural Kenyan school children. Br J Nutr 95, 379-390.

40. Murphy SP, Gewa C, Grillenberger M et al. (2007) Designing snacks to address micronutrient deficiencies in rural Kenyan schoolchildren. J Nutr 137, 1093-1096.

41. Neumann CG \& Harris DM (1999) Contribution of animal source foods in improving diet quality for children in the developing world. http://glcrsp.ucdavis.edu/projects/project_ subpages/CNP_folder/CNPWB.pdf (accessed November 2011).

42. Zijp IM, Korver O \& Tijburg LB (2000) Effect of tea and other dietary factors on iron absorption. Crit Rev Food Sci Nutr 40, 371-398.

43. Food and Agriculture Organization of the United Nations (2000) Special Report: Crop and Food Supply Situation in Kenya, 10 July 2000. http://www.fao.org/docrep/004/ x7697e/x7697e00.htm (accessed November 2011).

44. Gewa C, Murphy SP \& Neumann CG (2007) Out-of-home food intake is often omitted from mothers' recalls of school children's intake in rural Kenya. J Nutr 137, 2154-2159.

45. Beaton GH, Calloway DH \& Murphy SP (1992) Estimated protein intakes of toddlers: predicted prevalence of inadequate intakes in village populations in Egypt, Kenya, and Mexico. Am J Clin Nutr 55, 902-911.

46. Calloway DH, Murphy S, Balderston J et al. (1992) Village Nutrition in Egypt, Kenya and Mexico: Looking Across the CRSP Projects. http://pdf.usaid.gov/pdf_docs/PNABN873.pdf (accessed November 2012).

47. Ayele Z \& Peacock C (2003) Improving access to and consumption of animal source foods in rural households: the experiences of a women-focused goat development program in the highlands of Ethiopia. J Nutr 133, 11 Suppl. 2, 3981S-3986S.

48. Yeudall F, Sebastian R, Cole DC et al. (2007) Food and nutritional security of children of urban farmers in Kampala, Uganda. Food Nutr Bull 28, 2 Suppl., S237-S246.

49. Murphy SP, Gewa C, Liang LJ et al. (2003) School snacks containing animal source foods improve dietary quality for children in rural Kenya. J Nutr 133, 11 Suppl. 2, 3950S-3956S.

50. Ferguson EL, Gibson RS, Opare-Obisaw C et al. (1993) Seasonal food consumption patterns and dietary diversity of rural preschool Ghanaian and Malawian children. Ecol Food Nutr 29, 219-234.

51. Mitchikpe CE, Dossa RA, Ategbo EA et al. (2009) Seasonal variation in food pattern but not in energy and nutrient intakes of rural Beninese school-aged children. Public Health Nutr 12, 414-422.

52. Popkin BM (2002) An overview on the nutrition transition and its health implications: the Bellagio meeting. Public Health Nutr 5, 93-103.

53. Steyn NP, Nel JH, Parker WA et al. (2011) Dietary, social, and environmental determinants of obesity in Kenyan women. Scand J Public Health 39, 88-97.

54. Gibson RS (2005) Dietary strategies to enhance micronutrient adequacy: experiences in developing countries. In: Micronutrients in South and South East Asia: Proceedings of an International Workshop beld in Kathmandu, Nepal, 8-11 September, 2004, pp. 3-7 [SL Maskey, editor]. 
Kathmandu: International Centre for Integrated Mountain Development; available at http://books.icimod.org/uploads/ tmp/icimod_8f1ad2652b17b44c7ffaf65fbe5a7e48.pdf

55. Willett W (1998) Nutritional Epidemiology, 2nd ed. New York: Oxford University Press.

56. Kigutha HN (1997) Assessment of dietary intake in rural communities in Africa: experiences in Kenya. Am J Clin Nutr 65, 4 Suppl., 1168S-1172S.

57. Kennedy E, Bouis H \& von Braun J (1992) Health and nutrition effects of cash crop production in developing countries: a comparative analysis. Soc Sci Med 35, 689-697.
58. Kwena AM \& Baliddawa JB (2012) Nutritional status of children aged 6 to 59 months in community based education and service centres (COBES) in Western Kenya. Afr J Food Agric Nutr Dev 12, issue 3; available at http://www.ajol.info/ index.php/ajfand/article/viewFile/77102/67565

59. Smith LC \& Haddad L (2000) Explaining Child Malnutrition in Developing Countries: A Cross-Country Analysis. http:// www.ifpri.org/sites/default/files/pubs/pubs/abstract/111/ rr111.pdf (accessed November 2012).

60. Demment MW, Young MM \& Sensenig RL (2003) Providing micronutrients through food-based solutions: a key to human and national development. J Nutr 133, 11 Suppl. 2, 3885S. 